Syntax Fusion: Jurnal Nasional Indonesia

e-ISSN: 2775-4440

Vol. 1, No. 10, Oktober 2021

\title{
GAMBARAN RADIOLOGIS PADA BIDANG NEUROLOGIS STROKE
}

\author{
Ilma Fahira Basyir, Ninda Nurkhalifah, I Gusti Bagus Widiamatra Linggabudi \\ Fakultas Kedokteran, Universitas Mataram, Indonesia \\ Email: ilma.fakhira@gmail.com, ninda.nurkhalifah07@gmail.com \\ lingga230599@gmail.com
}

\begin{abstract}
Abstrak
Setiap gangguan neurologik mendadak yang terjadi akibat pembatasan atau terhentinya aliran darah melalui sistem suplai arteri otak mengacu sebagai istilah stroke. Stroke merupakan penyakit yang berada dimanapun dengan proporsi kejadian yang tidak tertandingi. Menurut World Health Organization (WHO) diperkirakan 17,5 juta orang meninggal dunia akibat penyakit kardiovaskular dengan 6,7 juta orang meninggal akibat stroke, yaitu urutan kedua tertinggi. Stroke dikategorikan menjadi 3 yaitu stroke iskemik/transient ischemic attack, stroke hemoragik, dan stroke transformasi iskemik menjadi hemoragik (IHT). Pencarian sumber dilakukan di portal online publikasi jurnal sebanyak 20 sumber yang berasal dari MedScape, Google Scholar dan Nation Center for Biotechnology Information/NCBI dengan kata kunci stroke dan radiolog of stoke. Perubahan iskemik fase awal dapat dideteksi dengan CT-scan tanpa kontras. Menunjukkan korteks insular yang tidak jelas dan ganglia basalis kanan tertutup, dengan hilangnya perbedaan abu-abu-putih dan hiperdens. MRI dan CT-scan memiliki sensitivitas yang sama dalam mengidentifikasi stroke hemoragik, namun MRI memiliki sensitivitas lebih tinggi dalam mengidentifikasi stroke hemoragik subakut. Diagnosis IHT hanya ditentukan dengan radiologi yang akan dikategorikan sebagai hematoma parenkim atau infark hemoragik. Stroke adalah kematian jaringan otak yang terjadi karena berkurangnya aliran darah dan oksigen ke otak. Stroke dapat berupa iskemik, hemoragik maupun transformasi iskemik menjadi hemoragik.
\end{abstract}

Kata Kunci: Stroke; Iskemik; Hemoragik; Transformasi; Radiologi

Diterima: 19-09-2021 Direvisi: 14-10-2021 Disetujui: 18-10-2021

\section{Pendahuluan}

Setiap gangguan neurologik mendadak yang terjadi akibat pembatasan atau terhentinya aliran darah melalui sistem suplai arteri otak mengacu sebagai istilah stroke atau penyakit serebrovaskular. Istilah stroke biasanya digunakan secara spesifik untuk menjelaskan infark serebrum. Istilah yang lebih lama dan masih sering digunakan yaitu cerebrovascular accident (CVA). Namun, istilah ini sulit dipertahankan secara ilmiah karena patologi yang mendasari biasanya sudah sudah ada sejak lama dan/atau mudah diidentifikasi. Karena itu, diduga proses terjadinya gangguan patologik seperti hipertensi 
menyebabkan stroke, sehingga stroke bukanlah suatu kecelakaan. Istilah lebih umumnya untuk masyarakat adalah serangan otak (Price \& Wilson, 2013).

Stroke merupakan penyakit yang berada dimanapun dengan proporsi kejadian yang tidak tertandingi. Menurut data World Health Organization (WHO) diperkirakan 17,5 juta orang meninggal dunia akibat penyakit kardiovaskular dengan 6,7 juta orang meninggal akibat stroke, yaitu urutan kedua tertinggi mengakibatkan kematian setelah penyakit jantung koroner. Lebih khusus lagi didefinisikan 1 kematian akibat stroke terjadi setiap 4 menit. Stroke banyak terjadi di negara berkembang, namun di negara maju seperti United State pun terdapat modalitas canggih untuk menangani penyakit ini. Stroke adalah penyebab utama kecacatan di US karena keparahan dan frekuensi kerusakan yang terjadi dan nyatanya, hanya $10 \%$ penderita stroke pernah pulih sepenuhnya. Menurut National Institutes of Neurological Disorders and Stroke, terdapat 5 jenis disabilitas yang terjadi setelah diberikan initial stabilization, yaitu paralisis atau gangguan motorik lain, gangguan sensorik, gangguan kognitif, dan gangguan emosional (Chandra, et al., 2017).

Sistem klasifikasi lama pada stroke biasanya membagi stroke menjadi tiga kategori berdasarkan penyebabnya: trombotik, embolik, dan hemoragik. Kategori ini sering didiagnosis berdasarkan riwayat perkembangan dan evolusi gejala. Dengan teknikteknik pencitraan yang lebih baru seperti CT scan dan MRI, kita dapat mendiagnosis perdarahan subaraknoid dan intraserebral dengan tingkat kepastian yang tinggi. Untuk kategori dasar dalam gangguan sirkulasi yang menyebabkan stroke, yaitu iskemia-infark dan perdarahan intrakranium, yang masing-masing menyebabkan $80 \%$ sampai $85 \%$ dan

$20 \%$ dari semua kasus stroke (Price \& Wilson, 2013). Sumber lain mengkategorikan stroke menjadi 3 yaitu stroke iskemik/transient ischemic attack, stroke hemoragik, dan ischemic to hemorrhagic transformation (IHT) (Chandra, et al., 2017).

Penulisan ini berfokus pada menjelaskan gambaran radiologis stroke iskemik, stroke hemoragik dan stroke transformasi iskemik menjadi hemoragik serta definisi, etiologi, epidemiologi, patofisiologi, manifestasi klinis, dan tatalaksana stroke.

\section{Metode Penelitian}

Penulisan artikel ini bersumber dari jurnal ilmiah dan pedoman pemerintah maupun instansi terkait yang relevan dan terfokus pada stroke dan gambaran radiologinya. Pencarian sumber dilakukan di portal online publikasi jurnal sebanyak 20 sumber yang berasal dari MedScape, Google Scholar (scholar.google.com) dan Nation Center for Biotechnology Information/ NCBI (ncbi.nlm.nih.gov) dengan kata kunci stroke dan radiology of stoke.

\section{Hasil dan Pembahasan}

Stroke adalah gangguan saraf yang ditandai dengan penyumbatan pembuluh darah. Gumpalan terbentuk di otak dan mengganggu aliran darah, menyumbat arteri dan menyebabkan pembuluh darah pecah, menyebabkan pendarahan (Kuriakose \& Xiao, 2020). Stroke terbagi menjadi 3 klasifikasi yaitu stroke iskemik/transient ischemic attack, 
stroke hemoragik, dan ischemic to hemorrhagic transformation (IHT) (Chandra, et al., 2017).

Stroke iskemik ditandai dengan hilangnya sirkulasi darah secara tiba-tiba ke area otak, mengakibatkan hilangnya fungsi neurologis yang sesuai. Stroke iskemik akut disebabkan oleh oklusi trombotik dan embolik arteri otak dan lebih umum daripada stroke hemoragik (Randolph, 2016). Stroke hemoragik disebabkan oleh pendarahan ke otak oleh pecahnya pembuluh darah. Stroke hemoragik dapat dibagi lebih lanjut menjadi perdarahan intraserebral (ICH) dan perdarahan subarachnoid (SAH) (Unnithan \& Mehta, 2021). Stroke transformasi iskemik menjadi hemoragik adalah komplikasi infark iskemik serebral dan dapat secara signifikan memperburuk prognosis (Danziger, 2018).

\section{A. Etiologi}

Stroke iskemik dihasilkan dari peristiwa yang membatasi atau menghentikan aliran darah, seperti emboli trombotik ekstrakranial dan intrakranial, thrombosis in situ, atau hipoperfusi relatif. Ketika aliran darah menurun, neuron berhenti berfungsi. Meskipun berbagai ambang batas telah dijelaskan, iskemia dan cedera neuronal yang tidak dapat diubah umumnya diperkirakan dimulai pada tingkat aliran darah kurang dari $18 \mathrm{~mL} / 100 \mathrm{~g}$ jaringan / menit, dengan kematian sel terjadi dengan cepat pada tingkat di bawah $10 \mathrm{~mL} / 100 \mathrm{~g}$ jaringan / menit (Randolph, 2016).

Hipertensi adalah penyebab paling umum stroke hemoragik. Perubahan hipertensi menyebabkan perdarahan intrakranial non-lobar (ICH). Hipertensi akut, seperti yang terlihat pada eklampsia, juga dapat menyebabkan ICH, yang dikenal sebagai ICH postpartum (Unnithan \& Mehta, 2021).

Infark serebral masif adalah salah satu faktor paling berbahaya dari pengembangan HT. Korelasi positif antara area infark dan insiden HT, risiko HT meningkat ketika infark otak masif. Infark otak besar sering disertai dengan edema otak yang substansial, yang menghasilkan kompresi vaskuler perifer. Permeabilitas dinding vaskular yang ditingkatkan karena iskemia dan hipoksia yang berkepanjangan yang disebabkan oleh kompresi vaskular sangat meningkatkan kemungkinan HT setelah pelepasan edema. Pada pasien dengan infark serebral masif, penting untuk melakukan CT kranial atau Magnetic Resonance Imaging (MRI) secara teratur, terlepas dari apakah gejala klinis memburuk atau membaik (Zhang, et al., 2014).

\section{B. Epidemiologi}

Stroke adalah penyebab kematian kedua yang paling umum dan ketiga penyebab paling umum dari kecacatan di seluruh dunia. Secara global, 68\% dari semua stroke iskemik dan 32\% stroke hemoragik. Di USA sedikit berbeda, $87 \%$ dari semua stroke adalah iskemik, $10 \%$ hemoragik dan sekitar 3\% menjadi perdarahan subarachnoid. Data mengenai prevalensi stroke di India kurang namun, dapat diekstrapolasi dari data yang tersedia dari barat. pada tahun 2001 tingkat prevalensi stroke di India adalah 147/100.000 dan tingkat insiden tahunan adalah 36/100.000. Tingkat prevalensi wanita menurut usia yang jauh lebih tinggi (564/100.000 untuk wanita dan 196/100.000 untuk pria) dan tingkat insiden (204/100.000 untuk wanita dan 36/100.000 untuk pria). Prevalensi keseluruhan stroke berkisar antara 147-922/100.000. India memiliki beban tertinggi sindrom koroner 
akut (ACS) di dunia dan tiga faktor risiko paling umum untuk ACS adalah merokok (40\%), tekanan darah tinggi (38\%), dan diabetes (30\%) (Chugh, 2019).

Lima belas juta orang menderita stroke di seluruh dunia setiap tahun. Dari jumlah tersebut, 5 juta meninggal dunia dan 5 juta lainnya dibiarkan cacat permanen. Insiden yang disesuaikan usia dari total stroke per 1000 orang-tahun untuk orang berusia 55 tahun ke atas telah dilaporkan dalam kisaran 4,2 hingga 6,5. Insiden tertinggi di Rusia, Ukraina, dan Jepang (Montaño, et al., 2021).

IHT diperkirakan terjadi dalam substansial 30\%-40\% dari semua stroke iskemik, tetapi perkiraan berkisar dari serendah $18 \%$ hingga setinggi $71 \%$, tergantung pada apakah informasi itu berasal dari CT scan atau otopsi. IHT adalah penyebab utama kematian dini pada pasien stroke iskemik akut, setelah ditemukan bertanggung jawab atas 26-154 kematian tambahan per 1000 pasien stroke iskemik. Faktor risiko untuk IHT sebagian besar mencerminkan stroke iskemik dan hemoragik dalam isolasi. Faktor risiko yang termasuk keadaan antikoagulasi, hiperglikemia, dan kolesterol total rendah dan lipoprotein densitas rendah (LDL); keadaan antikoagulasi, bagaimanapun diendapkan, dianggap sebagai faktor risiko utama untuk IHT (Chandra, et al., 2017).

\section{Patofisiologi}

Stroke iskemik disebabkan oleh kekurangan darah dan pasokan oksigen ke otak; stroke hemoragik disebabkan oleh pendarahan atau pembuluh darah yang mengalami kebocoran. Iskemik berkontribusi sekitar $85 \%$ korban pada pasien stroke, dengan sisanya karena perdarahan intraserebral. Iskemik menghasilkan trombotik dan embolik di otak. Dalam trombosis, aliran darah dipengaruhi oleh penyempitan pembuluh darah karena aterosklerosis. Penumpukan plak pada akhirnya akan menyempitkan ruang pembuluh darah dan membentuk gumpalan, menyebabkan stroke trombotik. Dalam stroke embolic, penurunan aliran darah ke daerah otak menyebabkan emboli; aliran darah ke otak berkurang, menyebabkan stres berat dan kematian sel yang tidak tepat waktu (nekrosis) (Kuriakose \& Xiao, 2020).

Pada sumber lain menjelaskan mekanisme primer terbentuknya cedera sebagai akibat dari stroke merupakan rendahnya aliran darah secara terfokus pada parenkim serebral. Walaupun bermacam fenomena dapat menimbulkan terbentuknya iskemik tersebut, aterosklerosis yang besar merupakan pemicu yang sangat sering. Pada aterosklerosis, penumpukan dari material lemak pada subintimal arteri akan membentuk timbunan platelet. Timbunan platelet ini akan menarik trombin, fibrin, serta serpihan eritrosit yang berikutnya dapat mengalami koagulasi sampai berukuran besar yang akan menambah resiko stenotik pada vaskularisasi serebral. Stagnasi aliran darah lokal yang diakibatkan oleh stress robekan ringan pada bilik pembuluh darah yang diduga sebagai faktor predisposisi pembuatan serta pertumbuhan plak aterosklerotik pada sebagian bagian dari vaskularisasi serebral, semacam pada bulbus karotis.

Pada seluruh permasalahan, trombus yang dihasilkan hendak membuat sel yang ada di dalam parenkim serebral mengalami kekurangan oksigen yang dibutuhkannya untuk berfungsi yang berikutnya akan menimbulkan terbentuknya proses patologis. Tetapi, pertumbuhan plak serta terbentuknya stenosis tidak senantiasa terletak di tempat 
yang sama. Plak dapat berpindah ke dalam perputaran serebral dari posisi lain, apabila hal ini berlangsung hingga plak tersebut dinamakan emboli. Jantung, melalui peristiwa atrial fibrilasi, merupakan pemicu tersering terbentuknya perihal tersebut, tetapi emboli juga dapat berasal dari bagian lain dari sistem arterial yang mengalami kerusakan (Chandra et al., 2017).

Selain infark yang terjadi pada pembuluh darah besar, yang melibatkan arteri karotis, vertebralis, dan beberapa cabang besar dari circle of willis, pembuluh darah kecil (lakunar) yang mengalami infark juga merupakan etiologi utama. Biasanya infark ini dikarenakan lipohyalinosis atau microatheroma, namun kadang melalui mekanisme yang sama dengan proses blokade yang terjadi pada arteri yang lebih besar, blokade yang terjadi pada pembuluh kecil, arteri yang menembus dengan sudut yang sesuai akan menimbulkan defisit fokal yang menjadi ciri khas dari stroke. Sebab lain yang kurang sering ditemukan adalah diseksi arteri akut yang disebabkan oleh displasia fibromuskular, gangguan hematologi seperti anemia sel sabit, dan penyalahgunaan kokain atau amfetamin (Chandra et al., 2017).

Hasil dari iskemia yang berkepanjangan adalah kematian sel serebral. Jumlah aliran normal yang cukup untuk memenuhi kebutuhan energi dari jaringan serebral adalah $60 \mathrm{ml} / 100 \mathrm{~g} / \mathrm{menit}$. Jika jaringan tersebut mendapatkan perfusi dibawah 10 $\mathrm{ml} / 100 \mathrm{~g} / \mathrm{menit}$, maka kegagalan membran sel akan berakibat pada cedera otak dengan derajat keparahan dan irreversibilitas yang sejalan dengan durasi iskemia (Chandra et al., 2017).

Stroke hemoragik mempunyai wujud yang heterogen. Ruptur yang berlangsung pada pembuluh darah serebral akan menginisiasi patologi. Tetapi, ada perbandingan yang mencolok antara mungkin lokus yang mengalami ruptur. Kebanyakan dari stroke hemoragik diklasifikasikan sebagai perdarahan intrakranial (ICH) serta melibatkan perdarahan ke dalam parenkim otak. Pada populasi barat, peristiwa ini berkontribusi pada 5- 10\% dari total stroke secara keseluruhan, tetapi proporsi ini dapat bertambah sampai sebesar 22-34\% di populasi asia tenggara, amerika selatan, serta afrika. Jenis stroke ini dapat dipecah lebih jauh lagi ke dalam aspek- aspek etiologis yang ikut serta. Bila onset tidak dapat dikenal lewat aspek struktural maupun aspek patologis, hingga keadaan tersebut diduga sebagai ICH.

Di sisi lain, bila keadaan ini didahului dengan aspek yang sudah disebutkan sebelumnya, hingga keadaan tersebut diduga sebagai ICH sekunder. Aspek- aspek yang dapat menimbulkan ICH sekunder merupakan perdarahan dari tumor, perubahan stroke iskemik menjadi stroke hemoragik, trombosis sinus vena di dura, serta vaskulitis. Tidak hanya ICH, ada jenis stroke hemoragik lain yang butuh dipertimbangkan. Bagian yang lebih kecil tetapi tidak dapat dianggap remeh dari bermacam tipe stroke merupakan perdarahan subarachnoid (SAH) yang mempunyai insidensi sebesar 2- 7\% dari insidensi seluruh stroke. Kebanyakan dari perdarahan subarachnoid mengaitkan ruptur spontan yang berlangsung pada aneurisma serebral ke dalam cairan (Chandra et al., 2017).

Ruptur biasanya terjadi pada bagian akhir pembuluh darah yang telah mengalami pelemahan progresif yang diinduksi oleh hipertensi. Selanjutnya, awal dari ruptur akan 
memicu terjadinya ruptur dari pembuluh darah lain melalui mekanisme perlengketan. Akhirnya, hasil dari ruptur - ruptur yang terjadi ini adalah lebih banyak ruptur lagi melalui mekanisme yang serupa, dan terus berulang seperti itu seiring hematoma berkembang. Lokasi terjadinya kaskade ini pada kasus ICH biasanya adalah pada arteri kecil yang menembus parenkim serebral. Pada kasus perdarahan subarachnoid, yang melibatkan prekursor aneurisma, berbagai gangguan, termasuk cedera sel endotelial dan kerusakan pada tunika media arteri, diduga berinteraksi dengan respon inflamatori untuk memicu terjadinya ruptur. Aneurisma utamanya muncul dari sirkulasi anterior cabang arteri dari lingkaran willis, terutama dari arteri komunikans anterior (Chandra et al., 2017).

Meskipun pembesaran hematoma memiliki keterkaitan dengan defisit neurologik yang mengalami eksaserbasi dan prognosis yang buruk, menghambat perkembangannya tidak serta merta menghambat cedera otak yang disebabkan oleh ICH. Hal ini disebabkan oleh, selain karena cedera primer yang disebabkan oleh gangguan mekanis, terdapat juga berbagai mekanisme sekunder pada operasi yang bersamaan. Salah satu bentuk dari mekanisme tersebut melibatkan respon imun terhadap elemen darah. Elemen-elemen ini menyebabkan aktivasi dari mikroglia dan astrosit disekitarnya. Sel-sel ini berfungsi dengan tujuan adaptif yaitu mensekresikan factor-faktor neutrofik dan memfagosit infiltrate-infiltrat yang terkait dengan pembentukan atau perkembangan hematoma. Namun sayangnya, sel-sel tersebut juga memicu respon pro inflammatory yang dimediasi oleh sitokin yang memiliki potensi yang sangat besar untuk membuat atau memicu cedera pada jaringan otak. Mekanisme lain dari cedera sekunder adalah terbentuknya spesies oksigen reaktif (ROS) yang memiliki kaitan dengan besi dari sel darah merah yang mengalami lisis. Walaupun jalur-jalur cedera sekunder ini bukan merupakan topik yang hangat diperbincangkan untuk saat ini, namun hingga saat ini belum ada intervensi yang mampu menghindarkan jalur atau mekanisme tersebut (Chandra et al., 2017).

IHT bisa terjadi secara spontan atau setelah pemberian terapi dengan tPA. Sekali lagi, patofisiologi dari IHT sangatlah kompleks dan belum dipahami sepenuhnya hingga saat ini, namun diduga bahwa IHT muncul utamanya sebagai akibat iatrogenik dari terapi stroke iskemik: pemberian tPA; ditambah lagi, efek penghapusan yang telah dibahas sebelumnya yang mampu melarutkan gumpalan yang sangat krusial terhadap integritas hemostatik dari vaskularisasi serebral. Pedoman terapeutik yang ada saat ini tampak tidak cukup memproteksi dari kemungkinan ini. Dalam penelitian yang dilakukan pada tahun 1999, 61\% (96 dari 156) dari pasien dengan stroke iskemik menderita IHT setelah dilakukan pemberian streptokinase yang merupakan analog dari tPA, jika dibandingkan dengan 31\% (61 dari 154) yang diberikan placebo (Chandra et al., 2017).

IHT juga bisa muncul secara sekunder sebagai akibat dari kerusakan struktural yang disebabkan oleh stroke iskemik. Jumlah cadangan adenosin trifosfat di dalam neuron mengalami penurunan dalam waktu menit semenjak onset dari hipoksia, yang berakibat pada kerusakan dari berbagai jalur-jalur homeostatik termasuk jalur yang terlibat dalam pemeliharaan dari sawar darah-otak. Hal ini akan berakibat pada degradasi dari integritas sawar darah-otak. Ditambah lagi, inflamasi yang disebabkan oleh iskemik 
yang terjadi akan memicu makrofag untuk melepaskan IL-1beta and TNF-alfa yang keduanya akan meningkatkan produksi MMP yang selanjutnya akan memfasilitasi disrupsi dari sawar darah-otak. Inflamasi juga mengganggu komponen autoregulasi dari pembuluh darah serebral yang membuat pembuluh darah tersebut kurang mampu mengkompensasi perubahan hemostatik yang terjadi setelah area yang mengalami infark telah mendapatkan reperfusi. Akhirnya, disrupsi sawar darah-otak, saat dibarengi dengan hilangnya kemampuan autoregulatory, akan menjadi predisposisi lokasi infark dan ekstravasasi darah ke dalam parenkim otak selama proses reperfusi (Chandra et al., 2017).

\section{Manifestasi Klinis}

Manifestasi klinis secara umum dari stroke yaitu munculnya sakit kepala yang hebat, afasia (gangguan bahasa), hemiparesis (kelemahan otot pada salah satu sisi tubuh) dan facial palsy (kelemahan pada sebagian otot wajah). Manifestasi klinis yang timbul pada pasien stroke iskemik, yaitu muntah, disfagia, kebutaan monokuler, afasia/gangguan bahasa, gangguan sensorik dan motorik, hilangnya kesadaran, dan dapat mengganggu fungsi serebelar (Chandra et al., 2017).

Seseorang yang mengalami stroke hemoragik dapat timbul berbagai manifestasi klinis, seperti nyeri kepala, tekanan darah meningkat, muntah, kejang, lesu, penurunan kesadaran, bradikardi, kaku leher, kelumpuhan, kelumpuhan lapang pandang vertikal, ptosis dan pupil tidak reaktif. Tanda-tanda meningismus seperti tanda Kernig (nyeri saat meluruskan lutut saat paha ditekuk hingga $90^{\circ}$ ) dan tanda Brudzinski (fleksi panggul yang tidak disengaja saat menekuk leher pasien positif (Unnithan \& Mehta, 2021). Sebagian besar perdarahan di IHT tidak bergejala. Namun, dapat juga terjadi perdarahan yang simptomatis yaitu peningkatan 4 atau lebih skor National Institutes of Health Stroke Scale (NIHSS) dibandingkan dengan skor pre angiography, dalam 36 jam setelah dimulainya pengobatan dengan adanya indikasi perdarahan intrakranial dilihat dari CT-scan.

Manifestasi IHT dapat berupa kombinasi dari stroke iskemik dan stroke hemoragik. Diagnosis IHT hanya ditentukan dengan radiologi yang akan dikategorikan sebagai hematoma parenkim (PH) atau infark hemoragik (HI). PH mengacu pada hematoma intrakranial yang padat dan homogen dengan adanya gambaran massa. PH1 mendeskripsikan hiperdensitas homogen menempati $<30 \%$ zona infark dengan beberapa gambaran massa dan $\mathrm{PH} 2$ mendeskripsikan hiperdensitas homogen yang menempati > $30 \%$ zona infark dengan gambaran massa yang signifikan. Sedangkan HI, menggambarkan hiperdensitas heterogen yang menempati Sebagian wilayah iskemik tanpa efek massa. HI terjadi lebih sering terjadi dibandingkan PH (Chandra et al., 2017).

\section{E. Gambaran Radiologis}

Perubahan iskemik fase awal dapat dideteksi dengan CT-scan tanpa kontras (NCHCT). Perubahan tersebut dapat terlihat pada Gambar 1. (Tong, et al., 2014). 

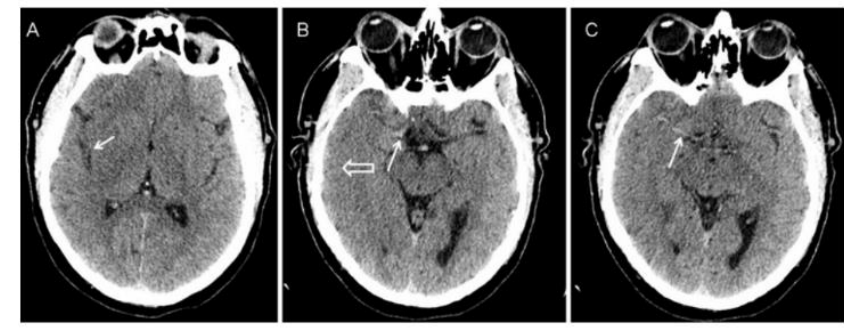

Gambar 1 CT-scan tanpa kontras fase awal stroke iskemik. Menunjukkan korteks insular kanan yang tidak jelas (panah, A) dan ganglia basalis kanan tertutup, dengan hilangnya perbedaan abuabu-putih (panah terbuka, B) dan MCA kanan hiperdens (panah, B dan C) CITATION Ton14 $\vee 1033$

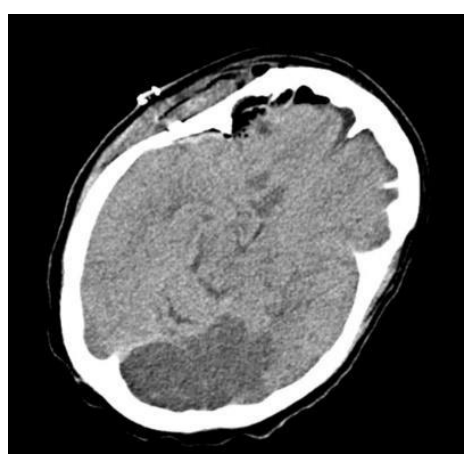

Gambar 2 Ct-Scan
Stroke Iskemik.
Bagian aksial pada
kepala CT nonkontras
menunjukkan stroke
iskemik PCA kiri dan
tidak ada perdarahan
CITATION Cha21 \l
1033 (Hui, et al.,
2021).

Tabel 1 Perubahan temporal menurut onset stroke iskemik pada MRI (Tong, et al., 2014).
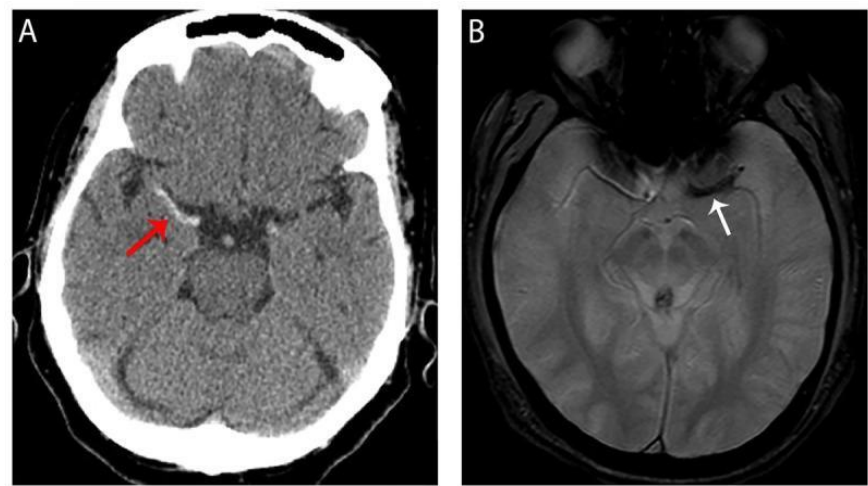

Gambar 4. CT-Scan dan MRI. Tanda arteri serebral tengah hyperdense dan artefak mekar. (A) CT kepala nonkontras yang menunjukkan arteri serebral tengah kanan yang hiperdens (panah merah). (B) Gradient recalled echo (GRE) MRI menunjukkan artefak mekar (panah putih) di arteri serebral tengah kiri. Kedua tanda tersebut menunjukkan trombosis. CITATION Lin16 \1 1033 (Lin \& Liebeskind, 2016).

Identifikasi dan pola darah pada CT kepala awal dapat menjadi acuan untuk neuroimaging berikutnya. Termasuk untuk kebutuhan mengulang kembali CT setelah beberapa jam untuk menilai perdarahan yang memburuk, edema, atau pergeseran garis tengah; kebutuhan CT-Angiography (CTA) atau Digital Subtraction Angiography (DSA) jika diduga terjadi perdarahan subaraknoid (SAH) atau intracranial hemorrhage (ICH) malformasi arteriovenosa atau fistula arteriovenosa; dan kebutuhan MRI otak (Hakimi \& Garg, 2016). 
MRI dan CT-scan memiliki sensitivitas yang sama dalam mengidentifikasi ICH akut, namun MRI memiliki sensitivitas lebih tinggi dalam mengidentifikasi ICH subakut. Susceptibility-weighted imaging (SWI) merupakan resolusi tinggi tiga dimensi gradient recalled echo (GRE) sekuens MRI yang paling sensitif digunakan dalam mendeteksi perdarahan jumlah kecil. GRE dua dimensi tradisional, yaitu $T 2 *$-weighted imaging dan MRI lainnya, seperti T1, T2, dan fluid attenuated inversion recovery (FLAIR) memberikan informasi penting. Paling penting, MRI memungkinkan adanya perbedaan antara dua etiologi ICH yang paling umum: hipertensi arteri vaskulopati dan amiloid otak angiopati (Hakimi \& Garg, 2016).
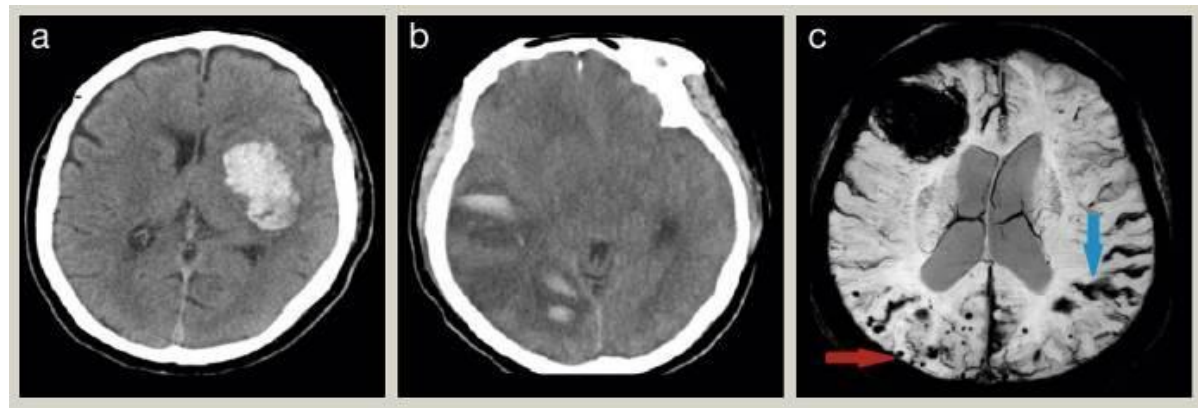

Gambar 7 CT-Scan Stroke Hemoragik (a)Pemindaian computed tomography (CT) aksial nonkontras yang menunjukkan perdarahan intraserebral di dalam ganglia basal. (b) CT scan aksial nonkontras yang menunjukkan infark hemoragik vena di regio temporoparietal kanan akibat trombosis sinus transversal kanan. (c) Perdarahan lobar, pewarnaan hemosiderin superfisial di dalam dan di sekitar sulkus serebral (siderosis superfisial kortikal, panah biru) dan mikrobled parenkim lobar (panah merah) konsisten dengan CAA. CITATION Mur20 \l 1033 (Murphy \& Werring, 2020).

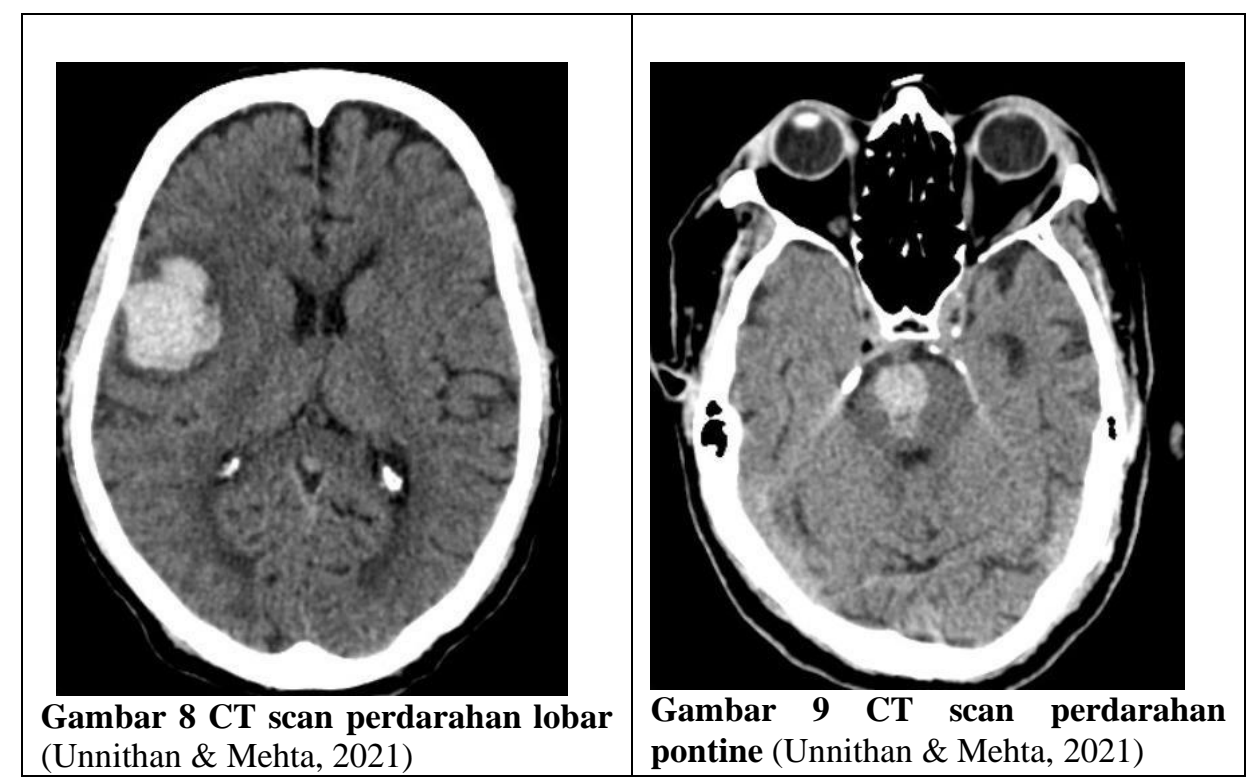


Ilma Fahira Basyir, Ninda Nurkhalifah, I Gusti Bagus Widiamatra Linggabudi

Tabel 2 Gambaran stroke hemoragik MRI menurut waktunya (Hakimi \& Garg, 2016).

\begin{tabular}{|c|c|c|c|c|c|}
\hline$\underline{\text { Stage }}$ & Phase of Blood & Noncontrast CT & $\begin{array}{l}\text { T1-Weighted } \\
\text { MRI }\end{array}$ & $\begin{array}{l}\text { T2-Weighted } \\
\text { MRI }\end{array}$ & $\begin{array}{l}\text { T2*-Weighted } \\
\text { MRI }\end{array}$ \\
\hline Hyperacute & Oxyhemoglobin & $\begin{array}{l}\text { Smooth, } \\
\text { hyperdense }\end{array}$ & $\begin{array}{l}\text { Hypointense or } \\
\text { isointense }\end{array}$ & Hyperintense & $\begin{array}{l}\text { Marked } \\
\text { hypointensity }\end{array}$ \\
\hline $\begin{array}{l}\text { Acute } \\
\text { (12-48 hours) }\end{array}$ & Deoxyhemoglobin & $\begin{array}{l}\text { Hyperdense with } \\
\text { fluid levels }\end{array}$ & $\begin{array}{l}\text { Isointensity } \\
\text { or slight } \\
\text { hypointensity } \\
\text { with thin } \\
\text { hyperintense } \\
\text { rim in the } \\
\text { periphery }\end{array}$ & $\begin{array}{l}\text { Hypointense } \\
\text { with } \\
\text { hyperintense } \\
\text { perilesional rim }\end{array}$ & $\begin{array}{l}\text { Marked } \\
\text { hypointensity }\end{array}$ \\
\hline $\begin{array}{l}\text { Early subacute } \\
\text { ( } 72 \text { hours) }\end{array}$ & $\begin{array}{l}\text { Methemoglobin } \\
\text { intracellular }\end{array}$ & $\begin{array}{l}\text { Hypodense } \\
\text { region of edema } \\
\text { with mass effect }\end{array}$ & Hyperintensity & Hypointensity & Hypointensity \\
\hline $\begin{array}{l}\text { Late subacute } \\
\text { (3-20 days) }\end{array}$ & $\begin{array}{l}\text { Methemoglobin } \\
\text { extracellular }\end{array}$ & $\begin{array}{l}\text { Less intense with } \\
\text { ringlike profile }\end{array}$ & Hyperintensity & Hyperintensity & Hypointensity \\
\hline $\begin{array}{l}\text { Chronic } \\
\text { (9 weeks) }\end{array}$ & $\begin{array}{l}\text { Hemosiderin } \\
\text { and ferritin }\end{array}$ & $\begin{array}{l}\text { Isodense or } \\
\text { modest confined } \\
\text { hypodensity }\end{array}$ & Hypointensity & Hypointensity & $\begin{array}{l}\text { Hyperintense or } \\
\text { isointense core } \\
\text { surrounded by } \\
\text { hypointense rim }\end{array}$ \\
\hline
\end{tabular}




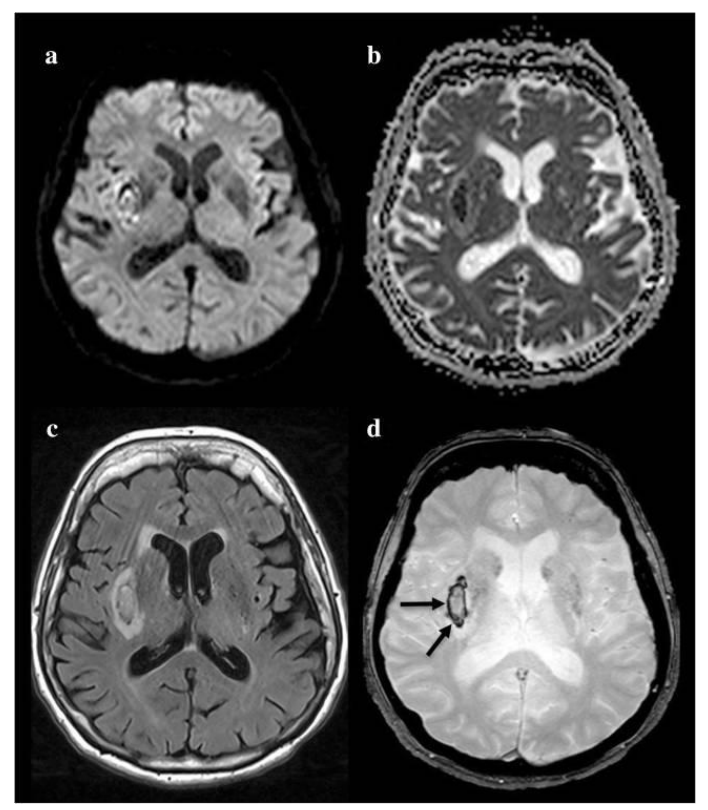

\section{Gambar 1.11. Gambaran MRI Fase Hiperakut Stroke Hemoragik.}

Seorang wanita 48 tahun dengan perdarahan intraserebral dengan gejala hemiplegia kiri dan hemianopsia homonim. DWI menunjukkan kelainan sinyal heterogen yang melibatkan nukleus lentikuler kanan pada b1000 (a), apparent diffusion coefficient (ADC) (b) dan fluid-attenuated inversion recovery (FLAIR) (c). Lesi muncul sebagai hipointensitas perifer pada T2 dengan pencitraan gradient recalled echo (T2-GRE) (d, panah) CITATION Gills V 1033 (Ferrier, et al., 2018).
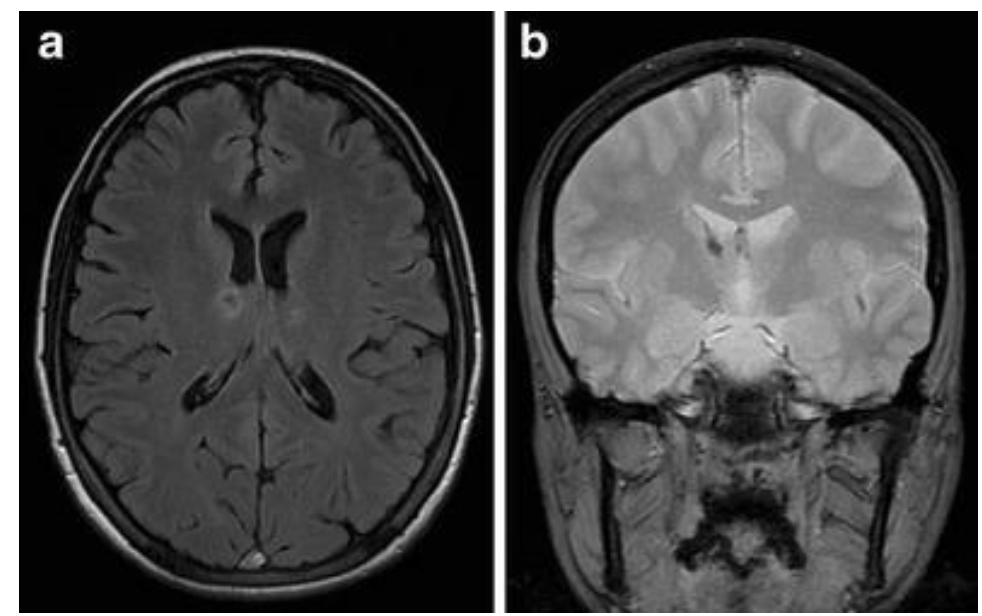

Gambar 1.12. Gambaran MRI Fase Akut Stroke Hemoragik. Infark hemoragik akut di talamus kanan akibat oklusi sinus vena pada wanita 30 tahun dengan riwayat kontrasepsi hormonal. gambar FLAIR dan gradien-echo T2-weighted imaging yang membuktikan transformasi hemoragik CITATION Vym12 \1033 (Vymazal, et al., 2012).

\section{F. Tatalaksana}

Stroke merupakan suatu kejadian yang berkembang, karena terjadinya jenjang perubahan metabolik yang menimbulkan kerusakan saraf dengan lama bervariasi setelah terhentinya aliran darah ke suatu bagian otak. Dengan demikian, untuk mengurangi 
morbiditas dan mortalitas perlu dilakukan intervensi secara cepat. Tujuan penatalaksanaan stroke ialah untuk memastikan kestabilan pasien dan mencegah atau membatasi kematian neuron (Price \& Wilson, 2013).

\section{Tatalaksana Umum}

Di Ruang Gawat Darurat hal pertama yang dapat dilakukan, yaitu stabilisasi jalan napas. Oksigen diberikan apabila saturasi $<95 \%$, intubasi endotrakeal dilakukan pada pasien dengan hipoksia, syok, dan berisiko mengalami aspirasi. Kemudian, stabilisasi hemodinamik dengan cara pemberian cairan kristaloid dan koloid. Untuk kasus ini hindari penggunaan cairan hipotonik. Lalu melakukan pemeriksaan awal fisis umum. Jika terdapat peningkatan tekanan intrakranial, dapat melakukan pengendalian peningkatan tekanan intrakranial dengan cara melakukan elevasi kepala pasien setinggi 20-30 derajat, jaga posisi agar tidak menekan vena jugular, hindari pemberian cairan glukosa dan cairan hipotonik, jaga normovolemia dengan melakukan osmoterapi apabila terdapat indikasi dengan memberikan manitol dan furosemid, dan terakhir untuk pemberian drainase ventrikular dianjurkan pada hidrosefalus akut akibat stroke iskemik cerebellum. Bila terjadi kejang pada pasien lakukan pemberian diazepam $5-20 \mathrm{mg} / \mathrm{kg}$ bolus dengan kecepatan maksimum $50 \mathrm{mg} /$ menit. Pasien perlu dirawat di ICU jika terdapat kejang. Kemudian evaluasi suhu tubuh pasien (Arifputera, 2014).

Saat pasien berada di ruang rawat jaga kondisi euvolemia dengan pemberian cairan isotonis, kebutuhan cairan total $30 \mathrm{ml} / \mathrm{KgBB} /$ hari, kemudian jaga kondisi elektrolit normal, koreksi asidosis dan alkalosis yang mungkin terjadi. Untuk pemberian nutrisi enteral paling lambat diberikan dalam 48 jam. Apabila terdapat gangguan menelan dan penurunan kesadaran, makanan diberikan melalui selang NGT. Kebutuhan kalori 25-30 $\mathrm{kkal} / \mathrm{KgBB} /$ hari. Lakukan mobilisasi dan cegah komplikasi subakut (aspirasi, malnutrisi, pneumonia, trombosis vena dalam, emboli paru, dekubitus, dan kontraktur) pasien yang berisiko mengalami trombosis vena dalam dapat diberikan heparin subkutan $2 \times 5000$ IU/hari. Dapat memberikan antibiotik, analgetik, antiemetik dan antagonis H2 bila ada indikasi (Arifputera, 2014).

2. Tatalaksana Khusus

Tabel 3 Kesimpulan Pengobatan (Chandra, et al., 2017)

\begin{tabular}{lll}
\hline CVD & $\begin{array}{l}\text { Pharmacological } \\
\text { interventions }\end{array}$ & $\begin{array}{l}\text { Procedural } \\
\text { interventions }\end{array}$ \\
\hline $\begin{array}{l}\text { Ischemic } \\
\text { stroke/transient } \\
\text { ischemic attack }\end{array}$ & $\begin{array}{l}\text { Thrombolytics (tPA) } \\
\text { Anticoagulants (heparin) }\end{array}$ & $\begin{array}{l}\text { Mechanical clot removal } \\
\text { Antiplatelets (aspirin) } \\
\text { craniotomy } \\
\text { Carotid endarterectomy }\end{array}$ \\
$\begin{array}{ll}\text { Hemorrhagic } \\
\text { stroke }\end{array}$ & $\begin{array}{l}\text { Calcium channel } \\
\text { blockers (nimodipine) }\end{array}$ & $\begin{array}{l}\text { Decompressive } \\
\text { craniotomy }\end{array}$ \\
& & $\begin{array}{l}\text { Surgical clipping of } \\
\text { aneurysms }\end{array}$ \\
IHT & None specific to IHT & None specific to IHT \\
\hline TPA=Tissue plasminogen activator, IHT=Ischemic to hemorrhagic transformation, \\
CVD=Cardiovascular disease
\end{tabular}


Sebagian besar pasien stroke mengalami peningkatan tekanan darah $>140 / 90$ mmHg. Pada pasien stroke iskemik akut tekanan darah diturunkan 15\% (sistolik maupun diastolik) dalam 24 jam pertama setelah awitan. Antihipertensi yang digunakan adalah labetalol, nitroprusid, nikardipin, atau diltiazem intravena. Pada kasus stroke, pengaturan gula darah juga menjadi penting karena hiperglikemia berhubungan dengan luasnya volume infark dan gangguan kortikal serta memperburuk prognosis pasien. Secara umum, hindari gula darah $>180 \mathrm{mg} / \mathrm{dl}$. Jika kadar gula $>180 \mathrm{mg} / \mathrm{dl}$ diturunkan dengan infus $\mathrm{NaCl}$ 0,9\%. Jika terjadi hipoglikemia $<50 \mathrm{mg} / \mathrm{dl}$ diatasi dengan pemberian bolus dekstrosa atau infus glukosa $10-20 \%$ sampai gula darah $80-110 \mathrm{mg} / \mathrm{dl}$.

Insulin digunakan pada pasien stroke akut disertai DM tipe 1 maupun II, namun tidak digunakan pada pasien stroke lakunar. Pemberian trombolisis pada stroke akut direkomendasikan pada pasien dengan presentasi stroke antara 3-4,5 jam dengan dosis recombinant tissue plasminogen activator (rTPA) $0,9 \mathrm{mg} / \mathrm{KgBB}$ (maksimal $90 \mathrm{mg}$ ). Pemberian antiplatelet aspirin dengan dosis awal $325 \mathrm{mg}$ dalam 24-48 jam setelah awitan. Pada pasien yang alergi aspirin atau yang sudah mengkonsumsi aspirin secara teratur, berikan clopidogrel $75 \mathrm{mg} /$ hari. Obat neuroprotektor Citicolin juga dapat diberikan pada pasien stroke akut dengan dosis awal 2 x $1000 \mathrm{mg}$ intravena selama 3 hari dilanjutkan 2 x 1000 mg PO selama 3 minggu (Arifputera, 2014; Price \& Wilson, 2013).

Terdapat banyak pendapat mengenai pengobatan stroke hemoragik, mulai dari penggantian faktor koagulasi dan trombosit jika pasien mengalami defisiensi. Apabila terdapat gangguan koagulasi dapat diberikan vitamin K $10 \mathrm{mg}$ intravena pada pasien yang INR meningkat dan fresh frozen plasma 2-6 unit. Selanjutnya, dapat melakukan pencegahan tromboemboli vena dengan stoking elastis dan pemberian heparin subkutan saat perdarahan sudah berhenti. Pada stroke hemoragik tekanan darah dan gula darah harus dikontrol juga. BP harus dikurangi secara bertahap menjadi 150 / $90 \mathrm{mmHg}$, menggunakan beta-blocker (labetalol, esmolol), ACE inhibitor (enalapril), calcium channel blocker (nicardipine) atau hydralazine. TD harus diperiksa setiap 10-15 menit.

Pengobatan penurun BP intensif dini melemahkan pertumbuhan hematoma selama 72 jam. Nila SBP tinggi dikaitkan dengan kerusakan neurologis dan kematian. Rekomendasi dari American Stroke Association (ASA) adalah bahwa untuk pasien dengan SBP antara 150 dan $220 \mathrm{mmHg}$, penurunan akut SBP menjadi $140 \mathrm{mmHg}$ aman dan dapat meningkatkan hasil fungsional. Untuk pasien dengan $\mathrm{SBP}>220 \mathrm{mmHg}$, diperlukan penurunan TD yang agresif dengan infus intravena kontinu. Untuk kontrol gula darah pada stroke hemoragik sama dengan kontrol gula darah pada stroke iskemik. Jika pasien mengalami kejang berikan antiepilepsi. Pemantauan lanjutan EEG diindikasikan pada pasien dengan tingkat kesadaran menurun. Kemudian, jika ditemukan peningkatan tekanan intrakranial lakukan pengendalian seperti pada tatalaksana umum. Pilihan terakhir yang dapat dilakukan yaitu operasi. Peran operasi pada stroke hemoragik adalah topik yang kontroversial. Indikasi melakukan operasi yaitu adanya perdarahan serebelum dengan perburukan neurologis, adanya kompresi batang otak, dan hidrosefalus akibat obstruksi ventrikel (Arifputera, 2014; Unnithan \& Mehta, 2021). 
Pada IHT induksi hipotermia terapeutik bisa memberikan manfaat kepada pasien tersebut karena telah terbukti dapat mengurangi ekspresi MMP setelah stroke. Pemberian awal deferoxamine adalah pelindung saraf terhadap perdarahan otak dan SAH, jadi kemungkinan akan memiliki efek serupa di IHT. Estrogen juga diketahui dapat melawan efek tPA yang tidak diinginkan serta untuk menurunkan BBB permeabilitas, aktivitas MMP-9, dan kejadian IHT. Phosphodiesterase-3 inhibitor cilostazol juga telah ditemukan dapat mencegah IHT bila diberikan sebelum tPA. Bukti menunjukkan bahwa cilostazol meminimalkan kerusakan endotel dengan mencegah apoptosis yang diinduksi lipopolisakarida dan menghambat adhesi neutrofil, dan hal itu diyakini mekanisme ini juga bertanggung jawab untuk mencegah IHT. Namun demikian, terlepas dari banyaknya kemungkinan terapi IHT, pencegahan sebaiknya dilakukan sebelum dimulai melalui pencegahan stroke iskemik sehingga menjadi pendekatan yang ideal (Chandra, et al., 2017).

\section{Kesimpulan}

Stroke adalah penyebab kecacatan nomor tiga dan penyakit mematikan kedua yang paling umum di seluruh dunia. Stroke adalah kematian jaringan otak (infark serebral) yang terjadi karena berkurangnya aliran darah dan oksigen ke otak. Stroke bisa berupa iskemik (sumbatan), hemoragik (perdarahan) maupun transformasi iskemik menjadi hemoragik. Penyebab dari stroke pun bermacam-macam mulai dari trombosis, embolism cerebral, iskemik hingga hemorragia cerebral (pecahnya pembuluh darah serebral dengan perdarahan ke dalam jaringan otak dan sekitarnya). Stroke dapat mengenai siapa saja terutama yang memiliki faktor resiko seperti hipertensi, penyakit kardiovaskuler, kolesterol, obesitas dan diabetes. Pada individu yang terkena stroke ada beberapa tanda dan gejala khas diantaranya munculnya sakit kepala yang hebat, afasia (gangguan bahasa) dan hemiparesis (kelemahan otot pada salah satu sisi tubuh) dan facial palsy (kelemahan pada sebagian otot wajah). Penatalaksanaan stroke dimulai dari mempertahankan fungsi vital seperti stabilisasi jalan nafas, oksigenasi dan sirkulasi. Lalu dilanjutkan dengan pemeriksaan fisik dan pemberian obat-obatan sesuai dengan etiologi yang dialami. 


\section{BIBLIOGRAFI}

Arifputera, A. (2020). Kapita Selekta Kedokteran. V ed. Jakarta: Media Aesculapius. Google Scholar.

Chandra, A., Stone, C R., Du, X. \& Li, W A. (2017). The Cerebral Circulation and Cerebrovascular Disease III: Stroke. Brain Circulation, 3 (2), 66-77. Google Scholar.

Chugh, C. (2019). Acute Ischemic Stroke: Management Approach. Indian Journal of Critical Care Medicine : Peer-reviewed, Official Publication of Indian Society of Critical Care Medicine, 23(2), S140-S146. Google Scholar.

Danziger, A. (2018). What Is the Pathophysiology of Hemorrhagic Transformation of Ischemic Stroke? Google Scholar.

Ferrier, G M., et al. (2018). Magnetic Resonance Imaging of Arterial Stroke Mimics: a Pictorial Review. Insights Imaging, 9(5), 815-831. Google Scholar.

Gaillard, F. (2020). Hemorrhagic Transformation of Ischemic Infarct. Google Scholar.

González, R G. (2013). Clinical MRI of Acute Ischemic Stroke. HHS Author Manuscripts, 36(2), 259-271. Google Scholar.

Hakimi, R. \& Garg, A. (2016). Imaging of Hemorrhagic Stroke. Continuum, 22(5), p. 1424-1450. Google Scholar.

Hui, C., Tadi, P. \& Patti, L. (2021). Ischemic Stroke. Google Scholar.

Kuriakose, D. \& Xiao, Z. (2020). Pathophysiology and Treatment of Stroke: Present Status and Future Perspectives. International Journal of Molecular Sciences, 21(20), 1-24. Google Scholar.

Lin, M P. \& Liebeskind, D S. (2016). Imaging of Ischemic Stroke. Continuum, 13 October, 22(5), 1399-1423. Google Scholar.

Montaño, A., Hanley, D F., \& Hemphill, J C. (2021). Hemorrhagic stroke. Handbook of Clinical Neurology, 176. Google Scholar.

Murphy, S J. \& Werring, D J. (2020). Stroke: Causes and Clinical Features. Elsevier Public Health Emergency Collection, 48(9), 561-566. Google Scholar.

Price, Sylvia A. \& Wilson, Lorainne M, 2015. Patofisiologi Konsep Klinis Proses-Proses Penyakit. VI ed. Jakarta: EGC. Google Scholar.

Randolph, S. A. (2016) Ischemic Stroke. Workplace Health and Safety, 64(9), 444. Google Scholar.

Tong, E., Hou, Q., Fiebach, J B. \& Wintermark, M. (2014). The rRole of Imaging in Acute Ischemic Stroke. Neurosurg Focus, 36(1), 1-17. Google Scholar. 
Ilma Fahira Basyir, Ninda Nurkhalifah, I Gusti Bagus Widiamatra Linggabudi

Unnithan, A. K. A. \& Mehta, P. (2021). Hemorrhagic Stroke. [Online] Available at: $\quad$ https://www.ncbi.nlm.nih.gov/books/NBK559173/ [Accessed 17 April 2021]. Google Scholar.

Vymazal, J., Rulseh, A. M., Keller, J. \& Janouskova, L. (2012). Comparison of CT and MR Imaging in Ischemic Stroke. Insights Imaging, 3(6), 619-627. Google Scholar.

Weng, L., Yao, D. \& Wang, R. (2020). Unusual Images of Ischemic Stroke with Hyperacute Spontaneous Recanalization: a Case Report. Annals of Translational Medicine, 8(16), 1-6. Google Scholar.

Zhang, J., Yang, Y., Sun, H. \& Xing, Y. (2014). Hemorrhagic Transformation After Cerebral Infarction: Current Concepts and Challenges. Annals of Translational Medicine, 2(8), 1-7._Google Scholar. 